\title{
A CONSTRUÇÃO DE PERSONAGENS NOS romances de Pepetela e a imaginação DA NAÇÃO ANGOLANA
}

\author{
Carolina Bezerra Machado (D) \\ Universidade Federal do Estado do Rio de Janeiro
}

No fundo, todos procuramos isso. O que é isso? Um conceito abstracto. Tenho a impressão que ninguém sabe muito bem o que é. No fundo, não conseguimos até hoje teorizar, definir o que é isso de angolanidade.

Isto, embora esteja patente na obra dos escritores angolanos, claro. Creio que é um conceito que se vai procurar ainda durante muito tempo.

Pepetela ${ }^{1}$

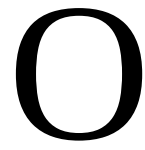

escritor colombiano Gabriel García Márquez, em uma de suas famosas frases, diz que todo escritor passa a vida a escrever um único livro. No caso de Pepetela, se tivermos que definir um tema que perpassa toda a sua obra, certamente é a angolanidade. Através de seus romances, somos remetidos à criação de novos referentes simbólicos para a nação que por vezes o aproximam e outras o afastam de uma concepção de identidade nacional defendida pelo Estado. Ao longo da década de 1980, os seus livros exploraram um projeto de nação muito próximo ao defendido pelo Movimento Popular de Libertação de Angola (MPLA), mesmo que muitas vezes apontassem para as insuficiências na criação da nação pelo partido. Por outro lado, à medida que as críticas ao burocratismo e a valorização de uma ideia plural de nação vinham à tona, a partir da década de 1990, o projeto concatenado a uma visão política, hoje vista pelo escritor como utópica, desagrega-se.

1 Apud Rita Chaves e Tânia Macedo (orgs.), Portanto... Pepetela, Cotia: Ateliê, 2009, p. 39. 
As incertezas quanto ao que poderia dar errado na formação da nação transformaram-se em certezas e desilusões.

Podemos notar o quanto as leituras sobre a nação, propostas nos romances de Pepetela, estão em diálogo com uma literatura que, historicamente, tem como característica fundamental escrever e pensar a nação angolana a partir dos seus fatores internos, por mais que também se valha de recursos e signos externos. O processo de criação de identidades perpassa fundamentalmente o ato de imaginá-las em contraponto aos registros das escritas coloniais ao valorizar os diferentes sujeitos envolvidos nesse processo. ${ }^{2}$ Essa escolha possibilita que fiquemos atentos aos novos signos, costumes e tradições encenados nos romances angolanos. Podemos, assim, ampliar as complexidades existentes no processo de criação do país ao nos deparamos com um rico processo de construção simbólica que desvela novos elementos para o desenvolvimento da nação.

Portanto, ao levarmos em consideração essas noções sobre a ideia de nação, devemos compreendê-las "não como entidades eternas mas sim situadas no tempo, históricas, logo, sujeitas às contingências e vicissitudes de processos históricos", ${ }^{3}$ do mesmo modo, passíveis de disputas políticas e de tensões em escala social que revelam o grau de força ou fraqueza a que estão submetidos os laços de unidade que compõem a nação. Nesse sentido, para Conceição Neto, a existência de uma angolanidade deve ser pensada não apenas a partir dos denominadores em comum partilhados entre a sociedade, mas também das diferentes identidades que compõem o cenário cultural angolano: "a nossa diversidade cultural pode ser a nossa força". ${ }^{4}$

Ao nos voltarmos para a composição da nação angolana, fundada a partir de diferentes grupos étnicos que não necessariamente desejavam a formação de uma unidade política, podemos complexificar as relações

2 Frank Marcon, “Os romances de Pepetela e a imaginação da nação”, História Revista, v. 16 (2011), p. 39 따.

3 Maria Eugênia da Conceição Neto, "As fronteiras por dentro da nação. Divisões étnicas, socioeconômicas e sociopolíticas numa perspectiva histórica”, Conferência Angola: a crise e o desafio democrático (Luanda, 1992).

4 Conceição Neto, "As fronteiras". 
sociais que marcam o processo de independência de Angola e da formação do Estado no pós-independência. Nesse sentido, não temos como falar de identidade nacional angolana sem nos remetermos ao período colonial, que "deixou marcas indeléveis nas estruturas econômicas e sociais, nos sistemas de valores e comportamentos", ${ }^{5}$ que contribuíram diretamente para a formação da nação angolana. A partir dessa perspectiva, devemos compreender a realidade nacional angolana em diálogo com o seu processo histórico, assim como a partir das diferentes "fronteiras” que cruzam o ideal de "identidade” a partir de uma concepção homogênea.

Em diálogo com essas noções, o nacionalismo angolano hoje tem sido definido a partir de sua expressão moderna ocidental, pois suscita um ideal coletivo a partir de um grau de unidade que propõe superar as divisões e identidades locais. ${ }^{6}$ Para Patrick Chabal, em Angola podemos notar a coexistência de três tipos diferentes de nacionalismo: o moderno - influenciado por modelos ideológicos europeus e em sintonia com as correntes de esquerda; o tradicionalista - defesa de uma realidade política imaginária puramente africana; e o étnico ou etnonacionalista - que colocaria em causa a continuidade das fronteiras traçadas pelo colonialismo. ${ }^{7}$ Destacam-se, nesse sentido, as organizações da União das Populações de Angola (UPA) e do MPLA em um cenário anterior à independência, colocando em evidência as disputas políticas e ideológicas que se intensificarão após o fim da época colonial. A busca de uma identidade própria perpassa concepções raciais, étnicas e regionais, que aparecem claramente nos discursos dos movimentos em busca de apoio popular. Essas disputas não vão ficar imunes ao cenário internacional de Guerra Fria, no qual os Estados Unidos (EUA) e a União Soviética (URSS) disputavam graus de influência no território angolano.

5 Conceição Neto, “As fronteiras”.

6 Fernando Tavares Pimenta, Angola no percurso de um nacionalista: conversas com Adolfo Maria, Porto: Afrontamento, 2006, p. 14.

7 Patrick Chabal, A History of Postcolonial Lusophone Africa, Londres: Hurst, 2002, pp. 5-8. 
Nos primeiros anos da Angola independente, o MPLA, movimento pioneiro na construção de uma imagem nacional para o recém criado Estado angolano, passou a defender o surgimento do homem novo, que não deveria ser apegado a concepções étnicas, tribais ou religiosas. O tradicional passava a ser visto como negativo e o desenvolvimento da nova nação deveria estar atrelado à ruptura com as etnias, os regionalismos, o racismo e as religiões. ${ }^{8}$ Tradição e modernidade apareciam como polos extremos de um problema a ser superado.

Quando nos voltamos para os debates sobre etnia dentro do campo político angolano, devemos demarcar as disputas e as problematizações que ainda cercam o uso do conceito. Durante muito tempo, uma das grandes chaves explicativas para se compreender os problemas enfrentados em Angola girou em torno dos conflitos étnicos. ${ }^{9}$ Assim, quando o MPLA assumiu o governo, rapidamente ganhou voz um discurso que pretendia deslegitimar os movimentos de oposição ao regime a partir dos seus componentes étnicos, caracterizados como obsoletos. As diferenças étnicas eram vistas por parte dos militantes do MPLA como grandes empecilhos para a construção da unidade nacional. Essa posição estaria ainda condicionada e, se legitimou entre muitos angolanos, por caracterizarem o conceito de etnia preso ao colonialismo e, por isso, tradicional e atrasado.

Ao problematizar essa posição, o interesse é lançar luz sobre as variáveis para estudar o nacionalismo angolano e as disputas em torno do conceito de etnia, pois a centralidade do conceito no estudo das sociedades africanas muitas vezes deixou de lado componentes sociais fundamentais que interferiram na formação dos movimentos nacionalistas. Nesse sentido, é válido ressaltar as aproximações entre os indivíduos, assim como a formação de movimentos políticos a partir de outros "vínculos de

8 Marcelo Bittencourt, “Angola: tradição, modernidade e cultura política” in Daniel Aarão Reis, Hebe Mattos, João Pacheco Oliveira, Luís Edmundo de Souza Moraes e Marcelo Ridenti (orgs.), Tradições e modernidades (Rio de Janeiro: FGV, 2010), pp. 129-144.

9 Bittencourt, “Angola: tradição, modernidade e cultura política”. 
solidariedade”, ${ }^{10}$ que perpassam a religião, a ideologia e outras clivagens culturais. Quando levamos em consideração essas noções, o conceito de etnia também passa a ser ressignificado. Para além de um conceito criado pelo colonizador para desqualificar as organizações sociais africanas, o fenômeno étnico também deve ser pensado dentro de sua historicidade, a partir de "unidades sociais desiguais e heterogêneas" e de processos históricos que o estruturaram e o compreendam para além de um sistema puramente colonial.

O conceito durante muito tempo foi interpretado pelas ciências sociais como um efeito do colonialismo, ou seja, um produto do sistema colonial na África, criado de modo artificial apenas para dividir as sociedades africanas. As etnias eram vistas como essencializadas e desprovidas de historicidade, o que silenciava toda a complexidade existente no interior dessas “cadeias de sociedades”. Deixava-se de lado, nesse caso, o quanto a etnicidade também fora uma forma de revolta anticolonial, em que “a afirmação étnica aparecerá como um meio de resistência”, contribuindo para o constante desenvolvimento das identidades étnicas até hoje. Assim, toda vez que o termo etnia aparecer na presente pesquisa, ele deve ser pensado também a partir destas noções, que ampliam o conceito e refletem as tensões que cercam os usos e reapropriações do mesmo. Por mais que o termo seja complexo, na medida em que foi criado com o objetivo de desqualificar e rebaixar as organizações políticas e sociais encontradas pelo colono no continente africano, Amselle e M'Bokolo chamam atenção para não refletirmos sobre o conceito a partir de uma tabula rasa, pois devemos pensá-lo a partir da sua variedade de sentidos, dentro de uma historicidade. Se, em um primeiro momento, as etnias foram criadas pelo colonizador a partir de relações hierárquicas de poder, em outro elas serão "reivindicadas pelos agentes que as transformarão em um instrumento ideológico de determinação social”. Ao deslegitimar esse movimento, as revoltas de caráter local contra o colonizador foram constantemente

10 Bittencourt, “Angola: tradição, modernidade e cultura política”, 2010. 
caracterizadas como "conservadoras e tribais”, à medida que se fortaleciam os movimentos de libertação e partidários. ${ }^{11}$

Em diálogo com essa perspectiva, ao nos voltarmos para a coleção Resistência, publicada pelo Departamento de Imprensa e Propaganda (DIP) do MPLA, que visava a publicação de panfletos que difundissem o ideal sobre o novo homem angolano, notamos que o objetivo principal seria "contribuir decisivamente para a educação política e ideológica das massas militantes”. Através da análise desses discursos, algumas questões centrais aparecem em evidência, como a posição de vanguarda assumida pelo MPLA para o rompimento com o colonialismo e a defesa de um novo projeto nacional voltado para concepções ideológicas socialistas. Para o então movimento, esta seria a única forma de atingir uma independência econômica e social, visto que na visão dos dirigentes, "o subdesenvolvimento de Angola seria consequência da dependência e exploração seculares do país pelo sistema colonial e imperialista”. ${ }^{12}$

Nas palavras de Agostinho Neto “a nossa luta é, no entanto, não só a necessidade de destruir o velho mas também e essencialmente construir o novo". ${ }^{13}$ Esse pronunciamento que, inclusive, intitula a coleção citada acima, fazia parte de um projeto político atrelado a uma concepção ideológica de formação do homem angolano, que deveria ser preparado para compor a nova sociedade que estava sendo construída. Nesse sentido, o art. $5^{\circ}$ da constituição de Angola ressaltava a importância de liquidar as sequelas "tribalistas” e regionais. ${ }^{14}$ A sociedade passava a ser pensada como um corpo uno e coerente a partir da uniformização de suas estruturas, dentre elas as culturais.

11 Jean-Loup Amselle e Elikia M’Bokolo, "Prefácio” in Jean-Loup Amselle e Elikia M’Bokolo (orgs.), No centro da etnia: etnias, tribalismo e Estado na África (Rio de Janeiro: Vozes, 2017), pp. 11-20.

12 Carlos Rocha Dilowa, Destruir para construir melhor, Luanda: Departamento de Informação e Propaganda, 1976, p. 6 (coleção Resistência).

13 Agostinho Neto, Destruir o velho para construir o novo, Luanda: Departamento de Informação e Propaganda, 1976, p. 8 (coleção Resistência).

14 Lei Constitucional da República Popular de Angola, Artigo $5^{\circ}$ apud Kelly Araújo, "Um só povo, uma só nação: o discurso do Estado para a construção do homem novo em Angola”, Dissertação (Mestrado em História Social), Universidade de São Paulo, 2005. 
Destaca-se também o investimento em organizações e associações que tinham como objetivo a criação de identidades coletivas que pudessem dar suporte ao projeto de nação angolana no pós-independência. Faziam parte dessa política a Organização da Mulher Angolana (OMA), criada ainda em 1961, a Juventude do MPLA (JMPLA), com função pedagógica doutrinária, e a Organização dos Pioneiros de Angola (OPA), que incluía entre os seus membros crianças entre 6 e 14 anos. Para Araújo, essas organizações contribuíam diretamente para o fortalecimento do enquadramento de personalidades coletivas, negando o individual e enfatizando uma cultura política que fortalecia a construção de um espírito identitário e nacional guiado ideologicamente pelo Estado. ${ }^{15}$

A formação de uma nova identidade nacional aparecia diretamente ligada ao fortalecimento do aparelho de Estado, assim como à sua burocratização. Como ressalta Kelly Araújo, por mais que houvesse uma articulação em integrar a sociedade nesse projeto, a defesa de uma identidade que unisse a imensa pluralidade angolana sempre partiu de cima, da aspiração de intelectuais e membros do Estado, o que dificultava o consenso. ${ }^{16}$

A historiadora chama a atenção para a "existência em Angola de 'fronteiras imaginadas' coexistindo dentro de um mesmo território politicamente definido", possibilitado por um processo de unificação ocorrido inicialmente a partir de uma "identidade contrastiva” em torno de um objetivo em comum: a expulsão do colonizador. ${ }^{17}$ Portanto, a partir do momento que esse objetivo foi alcançado, mesmo que inúmeros problemas já se fizessem presentes ao longo da luta, os desafios para a união da nação teriam ficado mais evidentes, encarados pelo MPLA como uma prioridade. Assim, a valorização do homem novo era vista como fundamental para o fortalecimento de uma concepção nacional atrelada ao regime político estatal.

15 Ver: Araújo, “Um só povo, uma só nação”, p. 80.

16 Araújo, “Um só povo, uma só nação”, p. 80.

17 Araújo, “Um só povo, uma só nação”, p. 72. 
Em entrevista, Pepetela comenta sobre a política nacionalista do MPLA:

Não fugimos à lógica que foi generalizada em África, com o Partido Único, uma ideologia dominando todo o resto, a tentativa de "modernizar" todas as estruturas de poder, domando as chefias tradicionais que ainda existiam aqui ou ali, a prevalência do Direito europeu sobre o costumeiro etc. Há muito que acho ter sido um erro apontar apenas numa direcção, o que, de certa forma, era copiar, mesmo pela inversa, o pensamento colonial. Acho que os africanos têm de pensar que é possível e necessário inventar modelos políticos e socioeconómicos que contemplem valores positivos das tradições. Talvez seja tarde demais, mas valia a pena tentar. ${ }^{18}$

O trecho acima explicita uma leitura reflexiva do autor após ser questionado sobre os contrapontos entre uma posição nacionalista totalizante, pretendida pelo Estado após a independência, e a sua escrita literária, que nos últimos anos vem reafirmando uma angolanidade pautada também a partir das diversidades culturais em Angola. O que podemos ver, a partir de uma posição que demonstra diálogo com a realidade política de outros países africanos, é a defesa de um novo modelo político que ressalte uma aproximação entre os aspectos internos da vida social daquela região em detrimento de uma sobreposição da cultura ocidental. Visto desta forma, a literatura de Pepetela abordada na presente pesquisa propõe uma aproximação entre tradição e modernidade. A nação seria pensada como intercambiante entre esses dois lugares, que não serão mais tratados como opostos.

Ao longo da década de 1980, a valorização da construção de um homem novo, atento às novas propostas modernizantes do regime - principalmente no que concerne ao marxismo-leninismo, ideologia adotada pelo MPLA desde 1977 - empurrou o tradicional ao arcaísmo, folclórico e

18 Pepetela, Entrevista concedida à autora via correio eletrônico, 25 jul. 2017. 
avesso às modernidades provindas com a independência. Encarado como “atrasado e refratário ao novo poder”, o tom assumido pelo Estado-partido era de confrontação ao tradicional, fosse ele de âmbito religioso, étnico ou educacional. Em tentativa de compreender o grau de enraizamento dessas novas orientações entre as camadas populares, Bittencourt buscou o quanto o tradicional passava a ser posto em tom de confrontação com o novo poder que defendia uma visão desenvolvimentista de ruptura com o local e regional por meio de músicas. O título das músicas de maior alcance aponta para as iniciativas sob a perspectiva do homem novo: "Rumo ao Socialismo", “Rumo à Independência Total” e "Será livre mãe”. Nesse sentido, atenta-se para a maneira como o rompimento com um passado de atraso - seja ele escravagista, seja colonial - teria como líder do processo o MPLA. ${ }^{19}$

Todavia, como ressalta o historiador, a partir das críticas de indivíduos do próprio partido, em finais da década de 1980, as denúncias de descompasso do governo com o socialismo e de avanço da corrupção, crescente centralização política e aumento do autoritarismo do Estado levaram ao questionamento das leituras modernizantes do governo, principalmente nas páginas literárias. As vivências tradicionais, por outro lado, voltaram a ser valorizadas entre os escritores.

O objetivo do presente artigo é analisar a partir das leituras de nação e raça - visto que nos romances de Pepetela a nação não é desvinculada das questões raciais - as complexidades que cercam a sociedade angolana no pós-independência. Em A geração da utopia, livro destacado para a análise, todos os personagens que vêm à narrativa são angolanos, e mesmo em meio à enorme diversidade existente entre eles o sentimento de pertença nacional faz parte de cada um, que o evoca à sua maneira. É relevante ainda o recurso discursivo do autor, que se debruça sobre as reflexões psicológicas de alguns desses personagens para abrir possibilidades de

19 De acordo com o escritor, o alcance das músicas, principalmente a partir da difusão da Rádio Nacional, contribui para conhecermos o quanto as perspectivas de um futuro perpassavam uma sociedade socialista, em oposição ao tribalismo e ao obscurantismo. Ver: Bittencourt, “Angola: tradição, modernidade e cultura política”, pp. 129-144. 
o leitor chegar às problematizações que cercam a questão nacionalista, envolta em um projeto de poder político que emerge em Angola a partir da independência em 1975.

Em diálogo com as argumentações desenvolvidas, não podemos esquecer a posição do intelectual em meio às suas escolhas políticas. O MPLA representava, enquanto movimento e organização partidária, um discurso agregador e crítico aos comportamentos racistas e tribais. Por isso, a partir de um discurso bem elaborado politicamente, conseguiu conciliar uma ampla rede de apoio que até hoje se coloca ao lado do movimento, por mais que existam críticas. Como relembra Fábio Baqueiro, por mais que a nacionalidade dos brancos estivesse sacramentada na legislação, "o reconhecimento da sua angolanidade [...] permanecia, em boa medida, uma concessão condicional”. Dessa forma, torna-se interessante nos voltarmos para o modo como Pepetela interpreta essa angolanidade e constrói os personagens brancos em suas tramas. ${ }^{20}$

Ao levarmos em consideração a produção intelectual do escritor devemos estar atentos para as interpretações e representações sobre nação, nacionalismo e identidade angolana. Inocência Mata destaca que a obra de Pepetela está inserida em uma tradição literária em que "a resistência, a afirmação identitária, a construção da nação, o projeto utópico e a celebração de um passado histórico" são marcas de um discurso da sua escrita, um discurso legitimo que detém grande autoridade. ${ }^{21}$ Os seus romances colocam em debate a identidade plural existente em Angola. Ao priorizar as diferenças, negam o ideal de nação coesa e harmônica pretendida no período pós-colonial. Somos envolvidos por uma (re)construção da nação angolana pautada pela diversidade em que a "construção de um programa do 'país ideal' ainda se pensa sobre novos procedimentos metodológicos”. ${ }^{22}$ Destaca-se ainda o

20 Fábio Baqueiro Figueiredo, "Entre raças, tribos e nações: os intelectuais do Centro de Estudos Angolanos”, (Tese de Doutorado), Universidade Federal da Bahia, Salvador, 2012, p. 362.

21 Inocência Mata, Ficção e história na literatura angolana: o caso de Pepetela, Lisboa: Colibri, 1993, p. 17.

22 Mata, Fiç̧ão e história, pp. 52-53. 
quanto, após um processo de desmistificação de uma grande utopia, pautada em valores marxistas-leninistas e na construção do homem novo, podemos visualizar nas obras de Pepetela um "deslocamento do centro para a margem, da sombra para a luz, do monólogo para o diálogo”, o que redimensiona a crítica política existente nos romances do escritor. ${ }^{23}$

Além disso, os romances de Pepetela são fundamentais na medida em que aparecem como parte essencial para a análise da nação angolana, não apenas entre os críticos literários, mas também entre cientistas políticos e historiadores, que constantemente se debruçam sobre a sua obra para analisar o imaginário angolano e as ideias que cercam e complexificam a ideia de nação em Angola. ${ }^{24}$ Por isso, também somos envolvidos pelas disputas que envolvem esse cenário, nas quais Pepetela continua atuante, contribuindo diretamente para a reflexão sobre a história oficial do país. A partir dessa posição, a produção literária aparece como uma dilatação da própria história, possibilitando reconstruções epistemológicas que questionam o status quo. Conforme sinaliza Rita Chaves, “o passado ganha sentidos múltiplos, o que interfere diretamente na leitura do presente e nas projeções do futuro realizadas pelos escritores angolanos”. ${ }^{25}$

\section{Nacionalismo nas páginas de A geração da utopia: "filho de cobra é cobra"}

Ao partirmos de um ditado popular largamente falado entre as fileiras guerrilheiras em Angola, podemos refletir o quanto as concepções raciais foram complexas e fizeram parte das tensões sociais no processo de

23 Mata, Ficção e história, p. 240.

24 É interessante, inclusive, destacar que os romances de Pepetela estão referenciados na grande maioria dos trabalhos de historiadores com os quais a presente pesquisa dialoga. Deste modo, pensar nação e raça em Angola necessariamente perpassa as narrativas do autor. Como exemplo, podemos citar os trabalhos de Marcelo Bittencourt, Fábio Baqueiro Figueiredo, Washington Nascimento, Kelly Araújo, Jean Michel Mabeko Tali, entre outros.

25 Rita Chaves, “O passado presente na literatura angolana”, Scripta, v. 3, n. 6 (2000), p. 245. 
construção da identidade nacional angolana. Nos romances de Pepetela inúmeras vezes o escritor faz referência a essa frase, assim como já a citou em algumas entrevistas, sobretudo, por ser um branco, angolano e participante das lutas de independência. Desta maneira, ao nos voltarmos para o modo como esses conflitos são vivenciados e interpretados nos seus romances, podemos presenciar o quanto a nação angolana foi imaginada, contribuindo de modo significativo para a nossa percepção sobre Angola. No caso, cobra é uma referência metafórica ao branco colonizador - o ditado propõe retomar uma imagem negativa acerca dos brancos e mestiços existente durante o contexto político no qual o livro fora escrito. Assim, a confiança nos brancos e mestiços era questionada, pois estes viviam sob a sombra da sua filiação, o que para muitos já os colocaria automaticamente do lado oposto das lutas angolanas.

A passagem abaixo retoma um momento do livro A geração da utopia (1991-1992). ${ }^{26}$ Desse trecho, destacamos a personagem Sara jovem estudante, frequentadora da Casa dos Estudantes do Império (CEI) e envolvida com movimentos nacionalistas. É possível percebermos, a partir dessas referências, a importância que Pepetela delega ao convívio em Lisboa para a formação política dos estudantes africanos.

Foram anos de descoberta da terra ausente. E dos seus anseios de mudança. Conversas na Casa dos Estudantes do Império, onde se reunia a juventude vinda de África. Conferências e palestras sobre a realidade das colónias. As primeiras leituras de poemas e contos que apontavam para uma ordem diferente. E ali, no centro mesmo do império, Sara descobria a sua diferença cultural em relação aos portugueses. Foi

26 Cabe aqui retomar a história central do livro. A geração da utopia é a saga de jovens angolanos que se conhecem quando vão para Portugal dar continuidade aos seus estudos e de lá passam a se relacionar de diferentes formas com os movimentos nacionalistas que emergem em Angola. A narrativa está dividida em cinco capítulos e perpassa desde os anos 1960 até a década de 1990. Ficam evidentes as contradições e ambivalências presentes no processo de independência do país e que fizeram parte da geração de Pepetela. 
um caminho longo e perturbante. Chegou à conclusão que o batuque ouvido na infância apontava outro rumo, não o do fado português. ${ }^{27}$

É válido salientar que Sara é uma personagem branca, nascida em Benguela. Estudante de medicina, teve seus estudos financiados pelo pai e, diferente de muitos outros estudantes, não passava por dificuldades financeiras. Aos poucos, ela vai se aproximando dos movimentos nacionalistas, principalmente do MPLA, o mais aberto à presença branca entre os seus quadros. Todavia, embora o movimento ressaltasse um discurso socializante, afastado de barreiras raciais e étnicas, Pepetela chama a atenção, nesse primeiro momento do livro, para o quanto a personagem Sara, apenas por ser branca, será consideravelmente afastada das discussões políticas e da participação efetiva no movimento, inclusive no momento de fuga de muitos estudantes em 1961.

Essas posições atestam para a distância que existia entre o discurso do movimento e a prática política, pois também havia a preocupação com a legitimidade institucional diante de um cenário marcado por rivalidades étnicas e raciais, embora cercado por ambiguidades. Por isso, por mais que acenassem com uma retórica socializante, em que todos deveriam ser tratados igualmente, sem distinções, ainda se mantinham presos às amarras sociais "retrógradas" ao se aterem à cor da pele para a escolha de seus membros. Através de uma narrativa sensível, Pepetela vai destacar os momentos em que Sara, ao mesmo tempo que passa a ser excluída de debates políticos, vai se enxergando cada vez mais próxima da sua terra natal, descobrindo, mesmo distante, as motivações que a levaram a se sentir como angolana. Demonstra que a cor da pele não interfere em nada no sentimento nacionalista que a leva a querer romper com a estrutura colonial e a sonhar com uma Angola livre.

Notrechodestacado, notamosentãooquantoaangolanidadedeSara foi construída fora deAngola, assim como outros personagens do romance,

27 Pepetela, A geração da utopia, São Paulo: Leya, 2013, p. 11. 
que terão suas identidades nacionais traçadas muitas vezes no exílio. "E a ideia cada vez mais mítica da terra longínqua, feita de impressões misturadas [...] A distância emprestava às coisas o tom patinado da perfeição”, ${ }^{28}$ Nesse sentido, devemos reconhecer o caráter agregador e de acolhimento da CEI, por mais que também devamos apontar as diferenças existentes entre os jovens que a habitavam: "O baile era o pretexto para as pessoas se encontrarem, refazerem as amizades. No entanto, havia grupos mais fechados e as diferentes fraturas, nacionais ou raciais, começavam a ser evidentes”. ${ }^{29}$ Ainda nesse sentido, a fala de Vítor, ao tentar convencer a jovem Fernanda a ir ao baile, ressalta a importância das atividades culturais da Casa; ${ }^{30}$ os estudantes africanos se sentiriam mais próximos de suas terras, a saudade seria apaziguada pela possibilidade de ter contato com pessoas com um passado em comum, assim como poder “dançar os ritmos de Angola, do Brasil ou das Caraíbas” contribuíam para acalmar o corpo. ${ }^{31}$

O receio da estudante angolana Fernanda é relacionado ao alerta da família: "Recebi uma carta do meu pai a prevenir-me para nunca lá pôr os pés, fazem política contra o governo. E eu cá nem percebo nem quero perceber de política”. A má fama da Casa, de acordo com ela, estava ligada à aproximação com o comunismo. ${ }^{32}$ Vinha de uma família em que o pai era colono da Madeira e de lá foi para o Lubango, território em que o racismo era muito forte, visto que boa parte da sua população era constituída por brancos. Essa realidade também fez parte

28 Pepetela, A geração da utopia, p. 11.

29 Pepetela, A geração da utopia, p. 113.

30 Vítor afirma: “A casa é uma associação que torna a vida mais fácil aos estudantes das províncias africanas - evitou o termo colônia para não a chocar. - Temos uma cantina onde se come mais barato que em qualquer outro sítio. E um posto médico. E há muitas atividades culturais e de recreio”. Pepetela, A geração da utopia, p. 104.

31 Pepetela, A geração da utopia, p. 105.

32 Alguns estudantes da CEI se aproximaram da esquerda portuguesa e atuaram junto ao Movimento de Unidade Democrática (MUD). Alfredo Margarido, “A literatura e a consciência nacional” in Aida Freudenthal (org.), Antologias de Poesia da Casa dos Estudantes do Império 1951-1963 (Lisboa: Acei, 1994). 
da trajetória pessoal de Pepetela quando fora estudar na região. ${ }^{33}$ Dessa forma, é interessante notarmos como a CEI já era interpretada como um local de efervescência política em que as ideias políticas mais à esquerda eram enxergadas por pessoas próximas daquela realidade.

Em número especial da revista Mensagem, outrora publicada pela Casa, em comemoração a seu cinquentenário, somos envolvidos pela ampla narrativa que faz parte do imaginário sobre a CEI, principalmente pelo seu destaque como um “espaço de sociabilização anticolonialista”, um local de redescoberta da cultura africana e de denúncia ao colonialismo e autoritarismo português. ${ }^{34}$ É fundamental, nesse sentido, atentarmos para a construção de outras imagens sobre o continente, que vão de encontro à ideologia colonial e fundem novas perspectivas sobre a sociedade e o homem africano. Chama-nos a atenção ainda o testemunho de Manuel dos Santos Lima no periódico, e o quanto o escritor pontua que, embora fosse um espaço de grande efervescência nacionalista, havia também grande heterogeneidade entre os membros da CEI, “constituindo isso o seu mérito maior e fonte de todas as ambiguidades”. A partir desses cenários surgem diversas clivagens raciais, políticas e sociais. ${ }^{35}$

Há, em referência ao convívio nesse espaço, a construção de uma memória coletiva, pautada pela descoberta de novos valores culturais e de formação de identidade. O próprio Pepetela, em testemunho para a revista, revela o quanto o fato de ser escritor em grande parte se deve à CEI, pois se, para ele, escritor é aquele que sente a necessidade de transmitir algo que lhe toca e transforma, foi no convívio na casa que se deparou com novas realidades, sons e sabores que até então não lhe diziam muito, mas que

33 De acordo com o escritor, lá as crianças negras "recebiam tratamento diferenciado, sendo mais vigiadas e castigadas em sua disciplina”. Silvio de Carvalho Filho, "Negro e Branco em Pepetela” in Simpósio Nacional de História, 1999, Florianópolis, Anais (Florianópolis: ANPUH, 1999).

34 Cláudia Castelo, “Casa dos Estudantes do Império (1944-65): uma síntese histórica”, Mensagem, número especial (2005), pp. 25-31.

35 Manuel dos Santos Lima, “Recordando a Casa dos Estudantes do Império”, Mensagem, número especial (2005), pp. 97-99. 
guardavam um imenso significado. Ou seja, a Casa lhe "despertou o amor pela terra”, e daí que esse amor passou a ser a sua razão de ser. ${ }^{36}$

Cabe ainda, de acordo com Bittencourt, atentarmos para a memória construída sobre a Casa - ainda mais forte na década de 1990 - de que todos os membros da CEI eram politizados, nacionalistas e de esquerda. Esta posição deve ser problematizada, principalmente ao levarmos em consideração uma realidade política em que o autoritarismo do governo português dificilmente deixaria a instituição se manter por tanto tempo. Portanto, devemos reconsiderar esse protagonismo da Casa, que certamente ficou muito famosa pelos debates literários derivados do convívio entre os estudantes. ${ }^{37}$

Ao retomarmos as trajetórias individuais de grande destaque político da Casa, somos, inevitavelmente, levados a uma memória que anula as diversidades e homogeneíza os universitários que a frequentavam. ${ }^{38}$ Sabe-se o quanto a Casa foi impulsionadora de jovens que se alinharam a movimentos nacionalistas; a CEI encenada em A geração da utopia é vista principalmente a partir do olhar de estudantes comprometidos com as ideias independentistas. Por outro lado, o olhar atento do estudante Elias, de origem protestante, destoa desse núcleo e traz para a narrativa novas interpretações sobre o grupo. Em diálogo travado com Vítor, Elias lança luz sobre o elitismo presente entre os membros da Casa. Enquanto Vítor guarda um discurso próximo daqueles do MPLA, na medida em que acredita em um processo revolucionário que levará a uma sociedade justa e igualitária em que todos - brancos, negros e mestiços - possam conviver em harmonia, Elias nega esse otimismo:

36 Pepetela, “A CEI fez de mim um escritor”, Mensagem, número especial (2005), pp. 115-117.

37 Marcelo Bittencourt, "Diversidade, escolhas e contextos nas memórias da Casa dos Estudantes do Império” in Cláudia Castello e Miguel B. Jerônimo (orgs.). Dinâmicas coloniais, conexões transnacionais: Casa dos Estudantes do Império (Lisboa: Edições 70, 2017), p. 183.

38 Bittencourt, "Diversidade, escolhas e contextos", p. 183. 
Utopias! Isso não funciona na prática. Eu sei, são ideias que correm na Casa dos estudantes. A Casa é dominada pelos filhos dos colonos, sejam brancos ou mulatos. No fundo, querem apenas uma melhor integração no Portugal multirracial. Todos falam da independência, mas a ideia não é a mesma. É mudar para ficar tudo na mesma, com o português dominando o negro. $\mathrm{E}$ tu alinhas nessas utopias, porque o teu pai não é camponês. O meu é. E a única hipótese de estudar foi aproveitando a bolsa da minha Igreja. ${ }^{39}$

Mais uma vez as fissuras existentes entre os jovens nacionalistas vêm à tona. Nesse debate podemos destacar ainda "a ideia de independência” questionada por Elias. De acordo com ele, adepto de Fanon e da teoria de que a violência do oprimido poderia contribuir para superar os traumas causados pela violência dos opressores, a violência da UPA se justificaria. ${ }^{40}$ Alegava ser uma fase necessária para poder alcançar a consciência para se chegar ao levante nacionalista. De acordo com o personagem, era inevitável tocar na questão racial ao reafirmar a luta contra o colonialismo: “O camponês só pode ser mobilizado para a luta por formas bem concretas, que ele entenda, por exemplo, o ódio aos brancos ou a repartição da terra dos brancos”. ${ }^{41}$ Era muito claro para Elias que a questão da propriedade de terra em Angola perpassava a presença branca e não chegaria ao fim apenas com a luta contra o colonizador português, uma vez que aquele branco, nascido em Angola, também se sentiria com mais direitos de ocupar a terra, pois sua origem familiar certamente era

39 Pepetela, A geração da utopia. p. 96.

40 É importante destacar que, a partir de algumas entrevistas, podemos notar o interesse de Franz Fanon pela UPA. De acordo com Marcelo Bittencourt, a partir de documentos de Lúcio Lara e de entrevista concedida ao historiador em Luanda, Lara afirma que Fanon se posicionava a favor da UPA, salientando que a organização teria melhores condições para iniciar a luta armada em Angola e por isso defendia que o MPLA se comprometesse com esse movimento, mesmo que significasse a sua dissolução. Marcelo Bittencourt, “Estamos Juntos: o MPLA e a luta anticolonial (1961-1974)”, Tese (Doutorado em História), Universidade Federal Fluminense, Niterói, 2002.

41 Bittencourt, "Estamos Juntos”, p. 97. 
proprietária: "Esses transportam em si a supremacia da parte branca sobre a negra, vem desde a nascença”. ${ }^{42}$

Por outro lado, Pepetela pretende demonstrar por meio da construção imaginária da personagem Sara o quanto essa teoria não deveria ser generalizada. A estudante de medicina, ao longo do romance, sempre apareceu comprometida com os ideais de uma independência em que prevalecesse a justiça e a igualdade. Ela, inclusive, afirma que, se fosse o caso, escolheria a independência em detrimento dos seus pais:

Pessoalmente custava-me muito, claro. Mas escolhia a independência, não tenho dúvida. Embora não fosse certamente o tipo de independência que desejava.

$[\ldots]$

Os meus pais iam pagar por crimes que outros cometeram. Oh, o meu pai também não é nenhum santo, naquela terra ninguém enriquece a fazer ações de caridade... Mas crimes não cometeu. Espero que seja uma independência que permita distinguir as ações das pessoas, que haja justiça. ${ }^{43}$

Atrelada desde o início às causas nacionalistas, o desenrolar do romance também a posiciona como uma mulher próxima das questões sociais, principalmente ao utilizar o seu ofício, a medicina, como um meio de salvar vidas de pessoas desfavorecidas economicamente. Além disso, ela sempre se mostrou interessada em acompanhar o MPLA, atuando como médica na guerrilha. Através de Sara, foi construída uma mulher forte, independente, nacionalista, leal e idealista - apesar de branca.

Esse contraponto entre Elias e Sara é instigante. Enquanto o primeiro é negro, de origem camponesa, com os estudos financiados pela igreja protestante, sendo esta sua única alternativa para ascender socialmente, Sara tem família portuguesa e estudou em Portugal financiada pelo

42 Bittencourt, "Estamos Juntos”, p. 97.

43 Pepetela, A geração da utopia, p. 38. 
seu pai. Ainda assim, é a partir dela que vamos conhecer as complexidades que cercam a questão racial nesse contexto anterior à independência. Através dela somos remetidos ao cenário de hostilidade ao negro em Portugal e ao branco em Luanda no início da década de 1960: ${ }^{44}$

Ela sentia, havia muito subtilmente uma barreira que começava a desenhar-se, algo ainda indefinido afastando as pessoas, tendendo a empurrar alguns brancos angolanos para os grupos de moçambicanos. A raça a contar mais que a origem geográfica? Oh, já estou a ver fantasmas. Ela própria não notara, ao aproximar-se de grupos angolanos, algumas caras mais fechadas, conversas interrompidas? Sim, havia. Era normal. Em Angola tudo estava a tender para uma guerra racial, havia uma repressão seletiva. Isso provocava reflexos em Lisboa. ${ }^{45}$

A primeira parte do livro é narrada a partir da perspectiva de Sara; somos envolvidos pelos problemas internos e externos que afetam Angola por meio do olhar atento da personagem, que se mostra indignada diante de uma UPA que, pelo que se sabia "queria expulsar todos os brancos e mulatos de Angola”, ${ }^{46}$ o que poderia afetar diretamente a sua família - fazendeiros de café da região de Benguela. Nesse momento, as organizações políticas e nacionalistas eram formadas clandestinamente, tanto em Luanda quanto em Portugal. O romance inicia em 1961, ano da eclosão das guerras anticoloniais em Angola, e, a partir dos episódios

44 Em A geração da utopia, Pepetela aborda na primeira parte do livro o quanto a propaganda do governo salazarista, que ressaltava o crescimento da morte dos brancos em Angola, contribuía para um clima de hostilidade entre negros e brancos em Portugal. Essa tensão era vivenciada pelos personagens: “Convém a Salazar criar um clima de histeria coletiva, centenas e centenas de brancos trucidados pelos terroristas, Angola é uma fogueira imensa, temos de defender a Pátria e os portugueses. Para Angola em força! A propaganda estava a resultar, tinha de reconhecer. Um espesso clima de suspeição se abateu entre os africanos em Lisboa. Passaram a cochichar quando antes discutiam a altos gritos, sempre com gargalhadas no meio. E a população passou de repente a olhá-los com hostilidade”. Pepetela, A geração da utopia, p. 10.

45 Pepetela, A geração da utopia, p. 18.

46 Pepetela, A geração da utopia, p. 14. 
ocorridos em 4 de fevereiro ${ }^{47}$ e 15 de março desse ano, ${ }^{48}$ o clima político teria ficado ainda mais instável, ressaltando as complexidades existentes para a unidade do processo de independência. As informações eram imprecisas e obscuras, e a impressão que o livro pretende passar é que não se sabia ao certo em que ou em quem se podia confiar, assim como a filiação a alguma ideia política poderia ser fluida ou apenas um meio para alcançar seus interesses pessoais - como era o caso de Malongo. ${ }^{49}$

A historiadora Conceição Neto traz considerações importantes sobre a memória do 15 de março, que após a independência continuou tendo a sua recordação tensionada pelos conflitos partidários que se seguiram. De responsabilidade da UPA e reconhecido pela sua violência, o conflito, de origem anticolonial, trouxe à tona o recorte racial existente e a releitura de Fanon. ${ }^{50}$ Nesse contexto de tensão, a proposta político-ideológica do MPLA, por ser mais socializante, se ajustava melhor aos interesses dos jovens estudantes do romance de Pepetela. Por mais que tivessem informações desencontradas, sabiam que estava surgindo um grupo que defendia a construção de um projeto nacional que se colocava como agregador e amplo, afastando-se do "tribalismo" e "racismo" existente na UPA: “Ter de escolher entre o colonialismo e a UPA,

47 Data que marca o início da luta armada de libertação nacional em Angola a partir do ataque a prisões em Luanda por homens armados de catanas para resgatar presos políticos. O movimento foi reivindicado pelo MPLA, embora até hoje ainda esteja cercado de dúvidas e contradições. Ver: Jean-Michel Mabeko Tali, Dissidências e poder de Estado: o MPLA perante si próprio, Luanda: Nzila, 2001, v. 1, e Bittencourt, "Estamos Juntos”, 2002.

48 Ataque da UPA à região norte de Angola, mais precisamente nas fazendas de café. Lideradas por camponeses bakongo, principal base de apoio da UPA, o levante ficou conhecido pela violência contra famílias brancas, mestiças e de negros assimilados, além de ovimbundu que tinham vindo do sul para trabalhar na região. Marcelo Bittencourt, “Estamos Juntos”, p. 79.

49 Malongo é um personagem que faz parte da Casa do Estudantes do Império. Jovem jogador de futebol, acaba sendo afastado das suas pretensões esportivas por mau comportamento. Não se interessava pelos debates de política na Casa e, quando participava deles, era apenas através do contato que tinha com amigos que se envolviam diretamente nos movimentos políticos ou por meio de Sara, sua namorada.

50 Maria da Conceição Neto, “UPA e a Revolta do norte de Angola (1961)” in Miguel Cardina e Bruno Sena Martins (orgs.), As voltas do passado (Lisboa: Tinta da China, 2018), p. 64. 
realmente...”, por mais que admitissem - Sara e seu colega Aníbal que a UPA ainda pudesse ser a melhor opção. ${ }^{51}$ Além disso, o MPLA tinha como lideranças Viriato da Cruz e Mário de Andrade, intelectuais largamente conhecidos na CEI que emprestavam confiança e seriedade ao projeto, como afirma Aníbal.

Portanto, o romance constrói como ocorreu a aproximação desses jovens estudantes com o MPLA e, da mesma forma, as causas que os levaram a negar a UPA, vista como um grupo atrasado, preso às complexidades regionalistas e raciais, questões estas que não deveriam fazer parte de Angola na independência. Afinal, eles não se identificavam como angolanos? Nasceram em Angola e descobriram à distância o cheiro, o sabor e as sensibilidades que cercavam a terra natal. Sendo assim, por mais que em alguns momentos deste romance, mas também de outros seus, como é o caso de Mayombe, Pepetela apontasse para a pluralidade da formação da nação angolana, por outro lado, não deixava de ressaltar a ideia de nação defendida pelo MPLA.

Um dos poucos momentos do livro que temos uma alusão positiva à UPA, por mais que se reconheça a enorme influência exercida por ela em algumas regiões angolanas, é na fala de Elias. Para além de serem retratadas apenas as mortes dos fazendeiros e as povoações saqueadas no levantamento contra os brancos de Angola, o estudante trazia explicações plausíveis para os ataques, dentro de uma lógica revolucionária que tinha o camponês como o principal sujeito desse processo. ${ }^{52}$ Todavia, cabe lembrar que esse personagem será retomado ao final do livro como um charlatão ao participar como fundador de um templo religioso.

De toda forma, podemos atentar ao longo do romance para como as desconfianças aumentavam dentro das diferenciações raciais que se cruzavam com os ideais nacionalistas. E, embora o livro não seja

51 Pepetela, A geração da utopia, p. 20.

52 Havia um grande esforço das lideranças da UPA em atrelar o seu movimento a uma mobilização originada sobretudo em meios camponeses, "mas sabe-se que seus principais líderes eram originários de famílias influentes no norte da colônia, muitos deles urbanizados”. Bittencourt, “Estamos Juntos”, p. 37. 
autobiográfico, é inevitável que a construção dos seus personagens seja amparada pelas perspectivas de vida do escritor. Seu início é na CEI, local de destino de Pepetela quando da sua chegada a Lisboa. Os conflitos raciais estão presentes em toda a primeira parte, que vai até o exílio de alguns estudantes na França. É fundamental salientarmos que, a partir de uma política colonial que utilizava o componente racial para estratificar uma sociedade, existirão consequências inevitáveis para a formação dos movimentos nacionalistas.

Os debates sobre as questões étnicas e raciais ainda vinham acompanhados das rivalidades políticas existentes entre os jovens estudantes. Somos envolvidos por discursos comunistas e anarquistas, além de nacionalistas, que não necessariamente eram atrelados a uma família política. Para Carlos Serrano, as respostas anticoloniais surgidas nas lutas pelas independências foram dadas de diversas maneiras. ${ }^{53}$ Do mesmo modo, a narrativa de Pepetela chama a atenção para as diferentes culturas políticas circulantes entre as fronteiras de Lisboa e Luanda e que estarão presentes entre os movimentos de libertação, mesmo que muitas vezes de modo confuso e contraditório. Podemos notar nessa primeira parte do seu romance que o nacionalismo angolano se forma em meio a essas disputas internas, como ressalta Aníbal:

Os comunistas acham que se deve trabalhar no interior do regime e derrubá-lo por dentro. E os nacionalistas angolanos, cada vez mais radicais, pensam que os angolanos devem lutar em Angola, de forma absolutamente independente e sem ter nada que ouvir os papás da esquerda portuguesa. Lutamos pela independência do país e por isso devemos ter movimentos políticos absolutamente independentes. Somos nós, com a guerra em Angola, que vamos derrubar o fascismo. Esta é a maka. ${ }^{54}$

53 Carlos Serrano, Angola, nascimento de uma nação, Luanda: Kilombelombe, 2008, p. 129.

54 Pepetela, A geração da utopia, p. 58. 
Do mesmo modo, Marta, amiga de Sara,

Não se metia em organizações estudantis nem políticas, dizia, isso é perder tempo, os políticos começam por políticos e acabam todos em ladrões. A própria ideia de organização lhe causava desconfiança, alimentada por leituras dos anarquistas do século passado. Os únicos aristocratas da política, dizia ela, desinteressados. Quanto a Angola, aprovara imediatamente as ações armadas. Os angolanos estão a mostrar a estes políticos de esquerda, que só fazem revoluções nos cafés, como se resolvem as coisas. ${ }^{55}$

Ainda são incipientes as pesquisas sobre a relação entre o Partido Comunista Português (PCP) e os movimentos nacionalistas de Angola. Sabe-se que houve contato entre as células estudantis e o então clandestino PCP, que influenciava-os ideologicamente, inclusive, nas escolhas nacionalistas futuras. ${ }^{56}$ Todavia, as desconfianças entre os grupos eram inúmeras, o que teria contribuído para o afastamento. ${ }^{57}$ As informações sobre os grupos eram muitas vezes desencontradas: a Polícia Internacional e de Defesa do Estado (PIDE) não conseguia descrever com precisão a diferença entre os movimentos, mesmo entre o MPLA e a UPA. Por vezes eram colocados como grupos “comunistas”, mesmo mantendo relações independentes. ${ }^{58} \mathrm{O}$ contexto narrado por Pepetela também retoma essas

55 Pepetela, A geração da utopia, p. 64.

56 Sabe-se que Agostinho Neto e Lúcio Lara eram militantes do Partido. Inclusive, o PCP teria organizado a fuga de Neto para o Marrocos em 1962. Dalila Cabrita Mateus e Álvaro Mateus, Purga em Angola. Nito Alves, Sita Valles e Zé Van Dunem o 27 de maio de 1977, Lisboa: ASA, 2007, p. 28. Além disso, posteriormente, os comunistas portugueses viabilizaram passagens de avião para nacionalistas angolanos, a fim de promover uma integração internacional do movimento. Conseguiram, assim, passaportes para Paris "como etapa intermediária, talvez, de uma ida para Moscou, e forneciam cartas de recomendação para correligionários franceses”. Silvio de Carvalho Filho, Angola: história, nação e literatura (1975-1985), Curitiba: Prismas, 2016, p. 33.

57 Tali, Dissidências e poder de Estado, p. 50.

58 Bittencourt, "Estamos Juntos”, 2002; José Gonçalves, O descontinuo processo de desenvolvimento democrático em Angola, Lisboa: Centro de Estudos Africanos, 2004. 
confusões e, embora aponte para o conhecimento de leituras de anarquistas e comunistas entre os integrantes das organizações nacionalistas, fica claro que não existia um aprofundamento e nem mesmo um comprometimento com as suas ideias. Porém, todos concordavam em um ponto, como exemplifica a seguinte passagem: "Marta e Aníbal, mesmo com ideais políticos diferentes, tinham um vasto terreno comum, o ódio à ditadura de Salazar e a esperança na independência das colônias”. ${ }^{59}$

Por outro lado, o racismo ainda provocava medos e dúvidas quanto à consolidação de um projeto nacionalista que, de acordo com Sara, fazia com que as pessoas de cor diferente fossem vistas como estrangeiros indesejáveis. Era o que acontecia tanto em Lisboa quanto em Luanda. ${ }^{60}$ Nesse sentido, a construção do cenário angolano no início da década de 1960 perpassava, necessariamente, os embates raciais, que foram muito presentes e permaneceram após a independência.

Ao escrever o seu romance em 1991, Pepetela continua inserido em um ambiente no qual a questão racial aparecia no centro dos debates nacionalistas, principalmente nos interesses eleitorais do período. ${ }^{61}$ Até a independência, o principal rival do MPLA no campo do nacionalismo angolano era a UPA-FNLA; ${ }^{62}$ porém, nesse momento, a grande adversária política do partido passa a ser a União Nacional para a Independência Total de Angola (UNITA). ${ }^{63}$ De toda forma, esse ainda é um contexto político

59 Pepetela, A geração da utopia, p. 86.

60 Pepetela, A geração da utopia, p. 86.

61 A partir de um acordo de paz assinado em 1991 entre os movimentos beligerantes da guerra civil em Angola, de um lado o governo - que era o MPLA - e de outro a UNITA, anunciaram eleições gerais para o ano de 1992. Seriam as primeiras eleições do país, que acabaram por demonstrar o quanto as fissuras internas ainda eram dolorosas para a manutenção de uma unidade nacional. Nesse sentido, o teor das campanhas eleitorais foram marcadas pelas questões étnicas e raciais que traziam à tona um processo de construção nacional fraturado, com diferentes forças políticas querendo tomar o poder.

62 Em 1962 a UPA transforma-se em Frente Nacional de Libertação de Angola (FNLA).

63 A UNITA surgiu após uma dissidência da FNLA. Jonas Savimbi, o seu futuro presidente, passou a acusar os dirigentes da FNLA de tribalistas. Como a organização tinha como grande base de apoio os bakongo, as críticas de Savimbi apontavam para o favorecimento desse grupo dentro do movimento. Oficializada em 1966, após o 
em que o fator racial é preponderante dentro dos partidos políticos, ${ }^{64}$ atuando, inclusive, como elemento mobilizador entre os militantes. Do mesmo modo, a questão étnica também faz parte do debate.

Ao tratarmos do período em que o romance é escrito, é inevitável nos voltarmos para as mudanças políticas, sociais e econômicas que fizeram parte de Angola. As eleições também eram sensíveis aos novos discursos que circulavam entre a sociedade, e o MPLA se distinguia dos demais partidos pela sua capacidade de se modificar de acordo com as exigências das circunstâncias. Através da polarização das eleições entre o MPLA e a UNITA, podemos notar uma mudança no discurso nacionalista da década de 1980, marcado pela valorização da construção do homem novo, atrelado a uma visão coletiva e marxista-leninista. O MPLA da década de 1990 “traz em suas campanhas um tom conciliador”, em que há a aproximação às chamadas chefias tradicionais, que deixaram de ser vistas como obstáculos às ações de Estado, passando a ser valorizadas como pontos de contato e mediação com as diferentes populações”. ${ }^{65}$

Esse debate é fundamental para a análise de A geração da utopia, em que um mesmo período é observado novamente pelo escritor. Se em Mayombe tivemos a fase de guerrilha analisada por uma perspectiva que via nas diferenças étnicas e culturais angolanas um entrave para o desenvolvimento do nacionalismo, agora essas questões ganham novas

recrutamento de jovens angolanos na fronteira leste na região, a UNITA surgiu como uma força que se colocava ao lado dos guerrilheiros no interior de Angola. Marcelo Bittencourt, "Nacionalismo, Estado e guerra em Angola" in Norberto O. Ferreras (org.), A questão nacional e as tradições nacional-estatistas no Brasil, América Latina e África (Rio de Janeiro: FGV, 2015), pp. 231-255.

64 Em 1991 tivemos uma revisão constitucional que possibilitou, a partir dos princípios básicos de uma democracia partidária, a criação de diversos partidos políticos de oposição, mas nenhum deles conseguiu ascender politicamente, sobretudo, pela falta de recursos, que eram concentrado pelos dois grandes partidos: UNITA e MPLA. Ver: Marcelo Bittencourt; “Conflito, identidade e voto em Angola” in Alexandre Ribeiro, Marcelo Bittencourt e Alexsander Gebara (orgs.), África passado e presente: II Encontro de Estudos Africanos da UFF, Niterói: EdUFF, 2010, pp. 174-186; e Nuno Vidal e Justino P. Andrade, O processo de transição para o multipartidarismo em Angola; Lisboa: Firmamento, 2008.

65 Marcelo Bittencourt, “As eleições angolanas de 1992”, Revista TEL, v, 7, n. 2 (2016), p. 179 ש. 
interpretações. A segunda parte do livro se desenrola a partir de 1972, em uma fase da guerrilha em que aparecem nas disputas políticas os interesses individuais, assim como os diferentes discursos que marcarão as contradições dentro do MPLA. Cabe então conhecermos como Pepetela analisa esse processo político e interpreta o incipiente nacionalismo nessa fase lembrando que, de acordo com o escritor, essa parte do livro foi escrita logo após Mayombe, tendo ficado guardada para um momento oportuno. É importante, todavia, frisar que Pepetela escreve de um lugar que condena as ações da UPA, assim como desqualifica os seus ideais. Do mesmo modo, como militante do MPLA, é muito mais próximo das suas ideias políticas, mesmo que haja discordâncias em alguns momentos.

O segundo capítulo é narrado, sobretudo, a partir da perspectiva de outro dos personagens: Vítor - o Mundial. É interessante nos voltarmos para o contraponto que será desenvolvido nesse capítulo entre Mundial e o personagem Sábio, nome de guerra de Aníbal. Enquanto este é visto como um herói, que age em prol do coletivo e do bem de todos, Mundial será representado como um guerrilheiro que aos poucos se afasta dos interesses da sociedade e cada vez mais pensa e age a partir dos seus próprios. Sua personalidade é construída em contraste com a de Sábio, um homem que carrega esse nome de guerra não pelas suas características físicas: "Baixo, magro, sempre agarrado aos livros e às ideias, não era propriamente a imagem que se fazia de um herói”, mas, de acordo com ele: "Esse nome de Sábio veio do facto de ter um curso superior? Até tenho, mas quem o sabe? Deram-me esse nome porque passava demasiadas lições de moral, falava sempre em defesa do povo”. ${ }^{6}$

Podemos notar ao longo do romance o quanto Mundial vai reconhecendo aos poucos a sua inferioridade frente a Sábio, representado como o espectro do guerrilheiro. ${ }^{67}$ Sua personalidade vai sendo construída como

66 Pepetela, A geração da utopia, p. 56.

67 Tatiana Reghini Mattos, “As vozes narrativas de Pepetela: a geração da utopia e Predadores” Dissertação (Mestrado em Estudos Comparados de Literaturas de Língua Portuguesa), Universidade de São Paulo, São Paulo, 2013, p. 26. 
imune à corrupção, à individualidade, à soberba, tornando-se o grande exemplo de homem. Sábio se comprometerá com um projeto utópico de poder, que o levará a um processo de desilusão, conforme veremos.

Vítor era um jovem estudante, frequentador da CEI e, à medida que a história é narrada, conhecemos um pouco do seu caráter desviante. No primeiro capítulo do livro, estava comprometido com o movimento nacionalista que vinha surgindo, via com bons olhos a independência e o fato de entrar em um projeto guerrilheiro lhe atraía. Entretanto, o segundo capítulo começa com diversas reflexões de Mundial que o levam a um processo de desilusão que o faz romper com o projeto político pelo qual entrou na luta: “o tempo do romantismo havia passado”. ${ }^{68}$ Já estamos em 1972, são anos de guerra e os problemas internos começam a vir à tona. É nesse ínterim que suas concepções políticas se afastam do que Sábio defende, e começa a se construir o contraponto entre eles, no qual o narrador se aproxima de Sábio, ao representá-lo como um homem comprometido com as causas nacionalistas e coletivas em detrimento de um eu-individualista. Já na primeira parte, a personagem Marta afirma:

- Se não morrer, o que se enquadra melhor com a sua maneira de ser, vai desiludir-se. A tal revolução que tem à frente não vai ser como ele imagina. Nunca nenhuma é como os sonhos dos sonhadores. É um sonhador, apesar de toda a sua linguagem rigorosa de comunista. Acaba por ter ideias mais libertárias que as minhas, que ele chamava de anarquista. As revoluções são para libertar, e libertam quando têm sucesso. Mas por um instante apenas. No instante a seguir se esgotam. E tornam-se cadáveres putrefatos que os ditos revolucionários carregam às costas toda vida.

$[\ldots]$

É um sonhador, um utópico, pior que eu. Ou morre ou se desilude, não tem outra alternativa. ${ }^{69}$

68 Pepetela, A geração da utopia, p. 187.

69 Pepetela, A geração da utopia, p. 131. 
Marta é conhecida por ter ideias anarquistas, não acredita em nenhum sistema político, mas, por outro lado, se encanta com o modo como Aníbal vê a política. É a partir daí que o caráter e a personalidade de Aníbal o Sábio - vão se construindo. O exemplo de intelectual engajado e militante é constituído pelas suas escolhas políticas ao longo do romance. Primeiro, ao desertar do exército português prestes a ir para a guerra em Angola. Ao ser avisada, Sara pensa: “Aníbal não ia aparecer aos olhos do povo como um falabarato traidor. Desertava, dando o exemplo a muitos outros...” e, em seguida, lhe agradece, e Aníbal pergunta o porquê do agradecimento: "Porque não me desiludiste, é essa a imagem que quero guardar sempre de ti. A do tipo mais coerente que já conheci”. ${ }^{70}$ Presenciamos aqui o primeiro momento de Aníbal como herói, embora já tivesse tido posição destacada ao defender sua tese de fim de curso contra a política colonial portuguesa e a ascendência de posições autonomistas em Angola. ${ }^{71}$

É interessante notarmos o quanto a segunda parte do romance busca evidenciar um Aníbal extremamente comprometido com os ideais nacionalistas do MPLA de fortalecimento da identidade nacional angolana a partir de uma unidade. As diferenças são novamente deixadas de lado em nome do coletivo e da construção de uma nação que deveria estar acima das diversidades. Chama a atenção o fato de que, enquanto os outros personagens têm seus locais de origem discriminados - Vítor de Huambo, Sara de Benguela, entre outros -, Aníbal é apenas retratado como angolano; ${ }^{72}$ isto até surgirem os problemas internos no MPLA, quando vamos saber que ele é nortista, embora se veja apenas como angolano e nada mais. Nesse sentido, o narrador se coloca ao lado de Aníbal e defende uma noção de identidade próxima à do MPLA, que nega qualquer exclusão racial ou étnica.

Em um determinado momento dessa segunda parte, temos a construção de um cenário de tensão entre os personagens Mundial e Sábio, que, se a princípio parecem fruto das rivalidades regionais existentes no

70 Pepetela, A geração da utopia, p. 54.

71 Pepetela, A geração da utopia, p. 21.

72 Mattos, “As vozes narrativas de Pepetela”, p. 28. 
interior do movimento, logo percebemos que se devem também a interesses políticos e que já se desenrola uma realidade de disputas por poder e privilégios entre os militantes. As características positivas de Aníbal em contraste com as omissões de caráter de Vítor em alguns momentos levam o leitor a se aproximar muito mais das causas defendidas pelo Sábio, o herói do romance. Suas ideias ganham a simpatia, ainda mais ao nos voltarmos para Mundial, retratado como um sujeito apegado às questões materiais e ao prestígio político:

A contragosto, teve de reconhecer que o Sábio era o mais prudente dos dois. A ele a questão sempre se pusera: levar a mochila era sem dúvida mais seguro, nunca se sabe o que a próxima volta do caminho esconde; mas, além do tormento provocado pelo peso nas costas, também lhe fazia perder prestígio aos olhos do povo, pois é símbolo de importância ter um carregador que leve a mochila do responsável. O Sábio não se importava com isso e, afinal, quando chegavam a um kimbo desconhecido, ofereciam o melhor banco a ele e nunca ao Sábio, pois este levava a sua própria mochila, como qualquer guerrilheiro. ${ }^{73}$

A partir desse trecho, cujo relato também aparece em algumas entrevistas de ex-guerrilheiros, ${ }^{74} \mathrm{o}$ narrador novamente se posiciona ao lado de Sábio, ao exaltar o desapego do personagem aos favorecimentos possibilitados por ser comandante. Mundial, pelo contrário, não deixava de usufruir dos benefícios suscitados pela sua posição. O prestígio lhe atraía e aparecia em primeiro plano frente aos interesses coletivos. O segundo capítulo, ao voltar-se para as reflexões psicológicas de Mundial, inclusive para aqueles pensamentos que jamais poderiam ser falados, contribuem para a reafirmação da heroicização de Sábio. Nesse sentido, o medo aparece como uma constante e vem à tona a falta de habilidade de Mundial nas matas: "Sempre teve quem o guiasse, quem estudasse o terreno por ele. As

73 Pepetela, A geração da utopia, p. 149.

74 Bittencourt, “Estamos Juntos”; Tali, Dissidências e poder de Estado. 
suas preocupações eram outras. Os olhos não se exercitaram e agora são como cegos". ${ }^{75}$ A sua posição como um homem individualista ia aos poucos ficando muito mais evidente através das reflexões solitárias na chana.

Por meio do contraponto entre os dois personagens, Pepetela desmistifica a ideia de que todo comandante do Norte seria corrupto ou ligado às benesses que poderiam surgir pela sua posição. As constantes reclamações dos revoltosos do Leste ganharam novos contornos a partir do personagem Sábio, que traz críticas muito mais estruturais ao MPLA em detrimento dos fatores regionalistas e raciais, vistos como simplistas frente às contradições internas representadas em A geração da utopia:

- No entanto, também há privilegiados do Leste ou do Sul, como tu... Entre nós dois, quem é mais privilegiado? Diz sinceramente. Eu nunca mando ninguém no exterior comprar cigarros ou açúcar ou café. Nem tenho dinheiro para isso. Mas cada caravana que vem traz-te sempre coisas que manda comprar. Nunca fico com tecido que vem para o comando para dar às mulheres... ${ }^{76}$

Mundial afirma: “Ora, é porque recusas sempre a tua parte. Tinhas direito a ela."77

E Sábio responde, a partir de uma perspectiva muito mais enobrecida que aponta para novas reflexões sobre o movimento:

- Não, acho que não tenho direito. Acho mais justo que se distribua o tecido pelo povo, que anda nu. O mal é que vocês agora opõem-se aos do norte, não para corrigir os erros, mas para aproveitarem desse erros. Estaria do teu lado se dissesse o movimento não se preocupa com o povo, todo o tecido deve ser para o vestir, vamos acabar com os privilégios dos responsáveis, com o muatismo. Mas não, dizes

75 Pepetela, A geração da utopia, p. 156.

76 Pepetela, A geração da utopia, p. 174.

77 Pepetela, A geração da utopia, p. 174. 
é um direito ficar com uma parte, direito instituído pelos primeiros responsáveis e que o movimento tolerou. Mas para ter esse direito precisa ser responsável. Por isso corramos com os outros para nós gozarmos desse direito. Não estás a pensar em melhorar as coisas, em acabar com todos os erros que trouxeram a luta para trás. Estás como os outros, a pensar utilizar a situação atual em teu proveito. Isso tem um nome, é oportunismo. ${ }^{78}$

A Revolta do Leste teve um significado importante na vida do escritor, que já fazia parte dos quadros do MPLA quando se iniciou o conflito, considerado uma das primeiras dissidências do movimento. No seu romance, a Revolta aparece como uma disputa regionalizada por postos de comando, em que "os do Norte”, identificados como kamundongos, eram os detentores do poder, retratados por Mundial como novos colonizadores: “Os do Norte criaram a sua própria colonização. Recrutaram guerrilheiros locais mas eles eram os chefes". ${ }^{79}$ Os problemas que apareceram ao longo da guerra eram, de acordo com Mundial, derivados da presença dos nortistas, que teriam traído os ideais da revolução ao se apegarem aos privilégios. Por outro lado, Sábio combate essa interpretação e questiona essa visão dualista e regionalista de ver as complexidades internas.

Como afirma Tali, não é de se admirar que o MPLA tenha sido visto pela população do Leste como um grupo privilegiado. Na maioria das vezes os dirigentes militares eram originários do Norte, vistos por muitos como um grupo coeso, com hábitos "globalizantes”, ligados ao mundo urbano. Por isso, seriam "associados a todos os abusos, vícios e crimes de que os chefes militares se tornaram culpados - e também todos os dissabores sofridos no Leste pelo movimento de libertação". ${ }^{0}$ Essas acusações começaram a romper quando a guerra já estava saturada e os problemas passaram a ser mais notórios.

78 Pepetela, A geração da utopia, p. 174.

79 Pepetela, A geração da utopia, p. 170.

80 Tali, Dissidências e poder de Estado, p. 128. 
Nesse cenário de disputas de memória, principalmente durante a década de 1990, o personagem Sábio aponta para outros caminhos. A autoridade do seu discurso é construída ao longo do romance a partir da integridade depositada no personagem, levando-nos a aproximarmo-nos da sua visão sobre os embates internos do MPLA. Sábio critica os regionalismos, mas concorda que deve haver mudanças estruturais dentro do movimento, que chegou a um nível de exaustão diante do cansaço da guerra, da falta de apoio, da corrupção existente e dos oportunistas presentes no movimento. À medida que aponta para as fissuras, propõe superá-las por dentro para a fundamentação de um projeto nacionalista. Um nacionalismo uno, que enxergasse o povo angolano como um só, para além das suas particularidades. Inclusive, a posição defendida por Mundial é vista como atrasada:

- Reages como um homem do Sul, Mundial. É normal, diria eu, se não tivesses outra instrução. Se tivesse sempre vivido na mata, se o teu entendimento não ultrapassasse as fronteiras do teu Kimbo, a reação seria normal. Tu estudaste, andaste pela Europa, nasceste no Huambo mas viveste em cidades. Deves refletir menos apaixonadamente. Além disso, o Huambo não é o Leste nem mesmo o Sul. ${ }^{81}$

Se por um lado Sábio se aproxima do discurso do MPLA, à medida que enxerga a Revolta do Leste presa às questões tribalistas e aborda os debates regionalistas e raciais como avessos à modernidade e à construção do homem novo proposta pelo movimento, por outro, o personagem também busca negar essa bipolaridade regional, trazendo argumentações válidas para compreendermos os embates político-sociais existentes no período de escrita do livro - este capítulo fora elaborado, de acordo com Pepetela, na década de 1970. Para uma análise mais complexa do contexto retratado, é fundamental levarmos em consideração que as disputas por

81 Pepetela, A geração da utopia, p. 171. 
espaço e vantagens no MPLA passavam pelos "vínculos de solidariedade” que cruzavam a vida dos militantes, tais como a escola que frequentaram e os laços familiares e religiosos construídos ao longo da vida. ${ }^{82}$

Sabe-se que a direção do MPLA apresentou um discurso reducionista ao tratar da Revolta do Leste, ignorando reivindicações consideradas como pertinentes inclusive por militantes contrários à Revolta. ${ }^{83}$ Desde 1969, com o comandante Jibóia, havia um processo de crítica à direção do MPLA que foi ganhando contornos políticos e desembocou nas dissidências que se estenderam ao longo de 1972 e 1973 com a liderança de Daniel Chipenda. Caracterizar esse movimento como tribalista, como fez o MPLA, é não reconhecer as motivações que levaram centenas de guerrilheiros a se unir e reivindicar mudanças. Jibóia era um dirigente político mbunda, enquanto Chipenda era bailundo e, mesmo com essas diferenças, estavam unidos pelas mesmas questões. ${ }^{84}$

O próprio Pepetela, em entrevista, aponta para as limitações em descrever esse processo simplesmente como tribalista: “As pessoas não se revoltam à toa. [...] Eu também não estava nada de acordo com isso, [...] [com] toda a propaganda que foi feita contra a própria revolta do Leste. Parecia que era qualquer coisa montada”. ${ }^{85}$ Dessa forma, no romance analisado o escritor escolhe, a partir de novos enfoques narrativos, demonstrar o quanto são complexas e ambíguas as relações de poder que se estabelecem internamente no movimento, inverter determinadas acusações e realçar o quanto os desvios e privilégios não são característicos de um grupo. No caso, Sábio, vindo do norte, guardaria todos

82 Bittencourt, “Estamos Juntos”, pp. 582-583.

83 Lúcio Lara afirma: “As origens, no fundo, são estas: Os comandantes em geral tinham vindo do Norte - isso ainda hoje acontece -, até abusaram, alguns abusavam [...] Mas realmente havia, digamos assim, um favorecimento dos chefes em desfavor aos guerrilheiros, e esse tipo de tratamento acumulado juntou as razões que, já muito mais tarde, fizeram nascer a Revolta do Leste, o princípio da Revolta do Leste”. Entrevista de Lúcio Lara a Drumond Jaime e Helder Barber, 1999 apud Bittencourt, "Estamos Juntos”, pp. 627-628.

84 Tali, Dissidências e poder de Estado, p. 156.

85 Entrevista de Pepetela a Marcelo Bittencourt em 6 de fevereiro de 1995 apud Bittencourt, “Estamos Juntos”, p. 640. 
os atributos de um bom guerrilheiro, enquanto Mundial teria um caráter duvidoso, o que será comprovado ainda mais adiante na narrativa.

Portanto, pretende-se, a partir da criação discursiva desses personagens, problematizar uma concepção étnico-regionalista da guerrilha: o herói do romance seria desapegado dessas imposições, se reconheceria apenas como angolano e, embora enxergasse as fissuras existentes à sua volta, defendia que deveriam ser superadas, pois estariam ligadas ao atraso: "recuso-me a ver-te como do Centro ou do Sul ou do Leste. Somos apenas angolanos, é tudo”. ${ }^{86}$ Essa é uma das grandes diferenças entre Sábio e os demais e por isso ele seria uma voz dissonante. O que fica claro em A geração da utopia é o quanto os sentimentos de união e unidade não conseguem ultrapassar as diferenças, como ocorre em Mayombe. A postura otimista de anos atrás se perdeu e os interesses individuais passaram a imperar.

Por outro lado, no mesmo momento em que irrompe a Revolta do Leste, uma outra Revolta também passa a ser conhecida entre os quadros internos do MPLA a partir de 1974, a Ativa. É importante salientar o quanto esses movimentos estavam entrelaçados à vida de Pepetela, principalmente por ser um momento em que o escritor estava atuando na Frente Leste. Todavia, cabe também realçarmos os silenciamentos da sua obra, em que não aparecerão referências a essa Revolta, assim como também não teremos menção à Revolta Nitista de 1977. Talvez a escolha pela Revolta do Leste em detrimento das outras seja pelo fato de este ter sido o primeiro momento de uma real dissidência no movimento, em que os embates regionalistas, étnicos e raciais se entrelaçavam aos problemas internos relacionados às disputas pelo poder político. Todavia, em nenhum momento Sábio, o herói, resolveu desertar do MPLA, embora trouxesse novas propostas:

É mais urgente do que nunca a criação dum partido revolucionário dentro do movimento. Ele deveria ser o núcleo que dirigiria o movimento,

86 Pepetela, A geração da utopia, p. 181. 
o qual na prática se convertia em frente. Os elementos desse partido seriam escolhidos a dedo, só entrando os militantes sem mácula. ${ }^{87}$

Mas Mundial não acreditava nisso e novamente voltava a questionar a forma com que seria escolhida a comissão que, segundo ele, cairia da mesma maneira nas questões regionais: "Haveria uma maioria de homens do Norte e o povo não aceitava”. Mundial era insistente quanto à "igualdade no número de dirigentes do Norte e do Leste” para atrair o apoio do povo mais uma vez, mas Sábio acreditava ser uma utopia que levaria certamente à derrota para os “tugas". ${ }^{88}$ Essa passagem, que no livro aparece sem grandes desdobramentos, permite que questionemos a centralidade do movimento a partir da ideia de criação de um partido, cujo núcleo dirigente não fica claro por quem seria escolhido. Uma das grandes críticas tanto da Revolta do Leste quanto da Ativa era em relação ao autoritarismo e à centralização do movimento em torno de Agostinho Neto. Entretanto, o romance não parece se preocupar com essas questões. Inclusive, para Pepetela, talvez fosse mais fácil se aproximar de uma Revolta que tinha aspectos regionais do que da Ativa, com críticas contundentes ao núcleo do movimento e encabeçada por pessoas muito próximas ao escritor - foi a partir desse momento que a sua trajetória passou a se diferenciar da de muitos amigos seus, como Adolfo Maria e Maria do Céu Reis.

É importante lembrar que, durante os anos de escrita do romance, importantes mudanças políticas ocorreram em Angola; passou-se a vivenciar um contexto político em que se pregava a paz, o multipartidarismo, a democracia e a exaltação de um discurso conciliador, fundamental para a permanência desse estado. Retomar questões delicadas era complicado e não convinha naquele momento. Bittencourt chama a atenção para esse ponto ao analisar as entrevistas que lhe foram concedidas na década de 1990 e perceber que grande parte dos entrevistados pediam serenidade e culpavam a juventude por muitas das escolhas feitas. ${ }^{89}$

87 Pepetela, A geração da utopia, p. 180.

88 Pepetela, A geração da utopia, p. 180.

89 Bittencourt, “Estamos Juntos”, p. 640. 
Levando em consideração essas questões, é importante notarmos o quanto Sábio é retratado como uma voz isolada dentro do movimento. Isso fica ainda mais nítido na terceira parte do romance, já na década de 1980, em que Aníbal se distancia dos rumos tomados pelo MPLA no processo de formação do Estado. Por isso, volta para Benguela e se afasta do governo, diferentemente de outros parceiros seus na militância. Nesse momento, fica ainda mais evidente a sua caracterização como um utópico que, por não concordar com o desenrolar dos acontecimentos, é deslocado pelo narrador de todos os erros cometidos pelo governo, sendo “colocado junto às vítimas do que chama de “processo” político, pois ele se mantém fiel ao que acreditava, fiel a um movimento político visto no pós-independência como utópico. ${ }^{90}$ Como afirma Santos, podemos notar uma "dissociação entre a utopia de cunho socialista-revolucionário e a implantação do projeto político do MPLA em Angola”, o que acaba suscitando ao longo do romance em uma "desresponsabilização dos utopistas pela evolução da situação no país”. ${ }^{91}$

Presenciamos até aqui o quanto $A$ geração da utopia é um romance que fala sobre os sonhos de um grupo de jovens, concatenados às lutas de libertação do seu país. Os medos são entrelaçados aos rompantes de coragem e ousadia de jovens angolanos que propõem romper com a lógica colonialista, o que os leva a pegar em armas para conquistarem seus objetivos. Todavia, a longa guerra, tratada à exaustão no segundo capítulo, destrói esses sonhos, ou ao menos aniquila a inocência que os acompanhava na juventude. Aparecem os problemas internos, as disputas pelo poder político, assim como os diferentes projetos nacionalistas. A frustração com o contato mais direto com a guerrilha aparece nas entrevistas, em que tanto Pepetela quanto outros companheiros seus, como Adolfo Maria e Maria do Céu Reis, ficam surpresos com a corrupção existente e a falta

90 Alexandra Dias Santos, “Nação, guerra e utopia em Pepetela (1971-1996)”, Tese (Doutorado em Sociologia), Universidade de Lisboa, 2011, pp. 263-264.

91 Santos, “Nação, guerra e utopia”, p. 249. 
de necessidades básicas, contrabandeadas por integrantes do MPLA. ${ }^{92}$ A figura do guerrilheiro como herói se distancia à medida que eles se aproximam das fronteiras da guerra.

A segunda parte do romance ganha os contornos da desilusão, vivenciada a partir das perspectivas diferentes de Sábio e Mundial. Quando o interesse pelo poder passa a não ser mais apenas em nome do coletivo, mas assume contornos individuais, o ideal de identidade e coletividade criado no exílio pelos personagens entra em contradição, e ficam evidentes os novos problemas que se colocam para a formação do país angolano. Enquanto Sábio vai se afastar, Mundial vê novas formas de crescimento político pessoal, o que o leva a fazer parte do governo no pós-independência.

\section{Considerações finais}

Ao compreendermos que a construção do nacionalismo angolano deve ser analisada a partir de dois momentos, o da luta de libertação nacional e o da afirmação de novas entidades políticas, é fundamental que atentemos para os diálogos existentes entre a construção do Estado e a formação de uma identidade nacional em Angola. Através de A geração da utopia podemos ver o quanto o nacionalismo pode assumir posições de confronto com o Estado, mas também o quanto um ideal de nação pode ser trabalhado em prol de uma unidade.

Ao longo dessa narrativa, pudemos nos deparar com algumas questões que ainda aparecem como problemáticas para a formação da nação após a independência. Temas como etnia, raça, regionalismo, assim como as disputas políticas, ainda são muito presentes e ganham novos contornos com os debates entre os personagens. Um dos principais recursos discursivos de Pepetela em seus livros é o uso da polifonia, característica

92 Bittencourt, “Estamos Juntos”, p. 590. 
que lhe propicia debater um assunto a partir de diferentes perspectivas, enriquecendo as complexidades existentes em Angola. Essa possibilidade de enxergar a realidade traz novos questionamentos e as cisões internas aparecem acompanhadas de reflexões entre o narrador e os personagens.

As limitações ao alcance das ideias nacionais totalizantes, assim como à influência socialista, esbarravam em culturas políticas muito arraigadas em Angola. Portanto, mesmo escritos vinte anos após a independência, dentro de um cenário de crítica da literatura aos desvios do regime político, os personagens de Pepetela continuam levantando questionamentos sobre quem seria angolano. Do mesmo modo, as diferenças existentes no território continuam sendo uma realidade; elas não foram apagadas com a independência. Sendo assim, as mudanças de diretrizes nacionais do MPLA a partir da década de 1990, que deixavam de ser restritas às ideologias socialistas, trazem novas relações entre a sociedade e o Estado. O nacionalismo ainda continuava sendo um elemento mobilizador que ganhava ainda mais força a partir do prolongamento da guerra civil..$^{93}$

Recebido em 14 maio 2020

Aprovado em 23 out. 2020

doi: 10.9771/aa.v0i62.36840

93 Bittencourt, “As eleições angolanas de 1992”, pp. 170-192. 
Este artigo tem como objetivo refletir sobre a construção de um imaginário acerca da nação angolana nas páginas dos romances do escritor Pepetela (Artur Carlos Maurício Pestana dos Santos), mais especificamente em A geração da utopia, escrito entre 1991 e 1992. A partir de um debate sobre como os conceitos de nação e raça ainda permaneciam problemáticos no período pós-independência, podemos visualizar através do romance a tensão ainda existente na sociedade angolana nos anos 1990, parte de um debate político dentro do Movimento Popular de Libertação de Angola (MPLA) que influenciou diretamente o desenvolvimento de uma ideia de Estado e nação do país. Nesse sentido, os romances de Pepetela vão muito além de uma concepção de literatura pautada pela escrita ficcional, e passam a ser fundamentais para refletirmos sobre o imaginário angolano sob uma perspectiva histórica e política.

Pepetela | Angola | Nação

\section{The Construction of Characters in Pepetela's Novels}

\section{AND THE IMAGINARY OF ANGOLA}

This article analyzes the construction of a collective imaginary about Angola in the novels of the writer known as Pepetela (Artur Carlos Maurício Pestana dos Santos), more specifically, the novel A Geração da Utopia, written between 1991 and 1992. By discussing how the concepts of nation and race remained problematic in the post-independence period, we can see through the novel the tension still existing in Angolan society at that time he 1990s and which was part of a political debate within the People's Movement for the Liberation of Angola (MPLA), directly influencing the development of an idea of State and nation. In this sense, Pepetela's novels go far beyond a conception of literature as merely fictional writing, becoming fundamental for reflections on the Angolan imaginary from historical and political perspectives.

Pepetela $\mid$ Angola | Nation 